\title{
DRY COOLING TOWER PROGRAM: RESULTS OF INDUSTRIAL CONTACTS THROUGH AUGUST 1974
}

\section{。 Battelle}

Pacific Northwest Laboratories

Richland, Washington 99352

Quchors:

NOVEMBER 1, 1974 


\title{
NOTICE
}

This report was prepared as an account of work sponsored by the United States Government. Neither the United States nor the United States Atomic Energy Commission, nor any of their employees, nor any of their contractors, subcontractors, or thier employees, makes any warranty, express or implied, or assumes any legal liability or responsibility for the accuracy, completeness or usefulness of any information, apparatus, product or process disclosed, or represents that its use would not infringe privately owned rights.

\author{
PACIFIC NORTHWEST LABORATORY \\ operated by \\ BATTELLE \\ for the \\ U.S. ATOMIC ENERGY COMMISSION \\ Under Contract AT(45-1)-1830
}

\author{
Printed in the United States of America \\ Available from \\ National Technical Information Service \\ U.S. Department of Commerce \\ 5285 Port Royal Road \\ Springfield, Virginia 22151 \\ Price: Printed Copy \$4.00; Microfische \$2.25
}


BNWL -1878

UC-38, Special

Distribution

DRY COOLING TOWER PROGRAM:

RESULTS OF INDUSTRIAL CONTACTS THROUGH AUGUST 1974

November 1, 1974

BATTELLE

PACIFIC NORTHWEST LABORATORIES

RICHLAND, WASHINGTON 99352 


\section{CONTENTS}

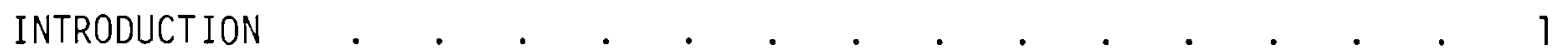

DESCRIPTION OF INDUSTRIAL CONTACTS . . . . . . . . . . . . . 3

Electrical Utilities . . . . . . . . . . . . . 3

Dry Cooling Systems Manufacturers and Vendors . . . . . . 4

Steam Turbine Manufacturers . . . . . . . . . . . 5

Architect Engineers . . . . . . . . . . . . . . . 5

DESCRIPTION OF DRY COOLED INSTALLATIONS OPERATING AND UNDER CONSTRUCTION

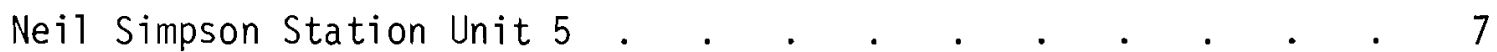

Wyodak Plant. . . . . . . . . . . . . . . . . 9

ADVANTAGES OF DRY COOLING

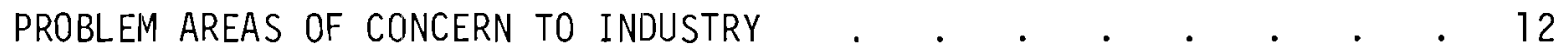

Costs . . . . . . . . . . . . . . . . . 12

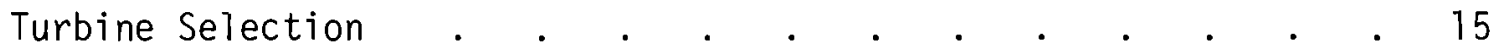

Experience and Reliability . . . . . . . . . . . . . 16

Operational Problems . . . . . . . . . . . . . . . 18

Freezeup Problems . . . . . . . . . . . . . 18

Water Treatment . . . . . . . . . . . . . . 19

Dependence on Weather Conditions . . . . . . . . 20

Long Term Degradation of Performance . . . . . . . 20

INDUSTRY COMMENTS ON PROGRAM CONTENTS AND SCHEDULES . . • . . . 22

Dry Cooling Practice and Experience . . . . . . . . 22

Costs . . . . . . . . . . . . . . . 22

Cost Definition . . . . . . . . . . . . . . . 23

Cost Reduction . . . . . . . . . . . . . 23

Innovative and Advanced Systems . . . . . . . . 24

Steam Turbines . . . . . . . . . . . . . . . . 24

Demonstration and Qualification Testing . . . . . . . . 25

Miscellaneous Problems of Dry Cooling . . . . . . . . . 26

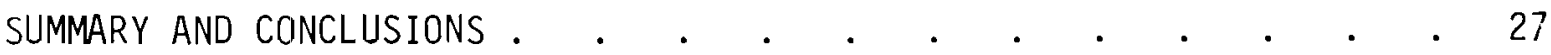

APPENDIX I: Listing of Industrial Contacts Through August 1974 . . 30 
DRY CONLING TOWER PROGRAM:

RESLILTS OF INDUSTRIAL CONTACTS THROUGH AUGUUST 1974

\subsection{INTRODUCTION}

The U.S. Atomic Energy Commission initiated the Dry Cooling Tower Program in mid-1974 to provide the technology to support the increased use of dry cooling ${ }^{(1)}$ for central power stations. This program will include research and development activities to provide solutions to the existing problems of dry cooling and the development and demonstration of new dry cooling concepts. The Pacific Northwest Laboratory was identified by the Commission to provide detailed planning and technical management of this program.

At the onset of program planning activities, it was recognized that an active working relationship with electrical utilities and equipment vendors is necessary to receive appropriate input and insure meaningful program results. Accordingly, as an early step in the program planning process, an industrial visitation task was initiated to establish these working relationships and to solicit the information required for planning a program relevant to industrial needs.

The organizations contacted initially were selected from those of having known requirements, interests and/or activities in dry cooling towers for central power stations. These organizations included electric utilities, architect engineers, dry cooling system vendors, turbine manufacturers, and others. Discussions were held with vice presidents, chief engineers and other officials of these organizations regarding their plans and concerns with regards to dry cooling and ways that the Dry Cooling Tower Program can

1) In this report, the terms "dry cooling" and "dry cooling tower" are used to denote the power plant heat rejection system or structure in which the rejected heat is transferred directly to atmospheric air across a solid interface without the evaporation of water. Although this terminology is somewhat confusing, it has apparently come into common use in the power industry as the antithesis of the term "wet cooling tower" and serves to contrast the basic difference between the two heat rejection concepts. 
best meet forecasted industrial requirements. This report describes the input received in these initial discussions. (2) As further significant results are obtained from the ongoing visitation activity, subsequent reports will be prepared and issued.

Some of the information received during these visitations were classified as "sensitive" by the organization contacted since its publication and/or association with the specific organizations could materially affect business, 1 icensing or other negotiations. Therefore, to maintain confidentiality of information where requested, full documentation of the information received is not provided in this report.

2) Through August 1974. 


\subsection{DESCRIPTION OF INDUSTRIAL CONTACTS}

A total of 28 organizations were contacted in the preliminary visitation activity. These organizations included 13 utilities, 3 architect engineers, 2 large steam turbine manufacturers, 3 dry cooling system vendors and 6 other organizations involved directly or indirectly in dry cooling. These 6 "other" organizations included the Electric Power Research Institute (EPRI), Heat Transfer Research Institute (HTRI), General Atomics (GA), PFR Engineering Systems, Inc., and Power Generating Cooling Systems Co. Although EPRI and HTRI have no efforts concerning dry cooling of central power stations currently underway, they were contacted at this early date to exchange information on research plans in the area and to establish a basis for coordinating future activities. General Atomic was included in the preliminary contact list because of their interests and activities in developing dry cooling for gas cooled reactor concepts and their interests in commercial production of dry cooling systems. Power Generating Cooling Systems $C_{0}$. was contacted to ostain detailed information regarding the potential benefits of the much publicized and novel ammonia absorption refrigeration cycle augmentation scheme for dry cooling proposed by $\mathrm{Mr}$. A. C. Smith of that company.

A list of organizations and individuals contacted is provided in Appendix 1 .

\subsection{Electrical Utilities}

Thirteen (13) electrical utilities were contacted. These utilities were located in the northeast, north-central, west coast and southwest regions of the United States. It was found that 12 of these had interests in dry cooling to the extent that they had or were engaged in one or more of the following activities:

- Performing cost and feasibility studies of dry cooling

- Sponsoring R\&D studies

- Cooperating in regional studies of the economics of dry cooling.

One utility, Black Hills Power and Light, has built and is operating dry cooled units at the Neil Simpson power station in northeastern Wyoming. 
The same utility in cooperation with Pacific Power and Light is presently constructing a $330 \mathrm{MW}$ dry cooled unit ("Wyodak Plant") immediately adjacent to the Neil Simpson Station.

Other utilities contacted indicated adequate water supplies in the near future for the construction of additional power plants with wet cooling towers. However, the approximate year after which dry cooling will have to be used in new construction was stated as 1985 ( 6 utilities), 1990 (3 utilities), 1995 ( 1 utility) and 2000 (1 utility).

The principal reason stated by utility officials for their consideration of dry cooling was the projected unavailability of adequate water supplies in future years (11 responses) due to depletion of ground water, complete utilization of available surface water supplies, and the increased competition for existing water supplies by an expanding population, industry and agriculture. In the intermountain states, the future development of a coal liquefaction and gasification industry and oil shale extraction is seen as providing additional competition for existing water supplies which may accelerate the requirements for dry cooling. Siting factors were also recognized as an important factor leading to consideration of dry cooling ( 5 responses), i.e., plants could economically be sited at the fuel source. Environmental reasons were cited by only 5 utilities.

of the utilities projecting the future need for power stations with dry heat rejection systems, 5 are planning or considering the use of "hybrid" (wet/dry) cooling towers in the near future to conserve existing water supplies. The approximate dates of these installations range from 1978 to 1986.

\subsection{Dry Cooling Systems Manufacturers and Vendors}

Meetings were held with officials of the Marley Co., Hudson Products Corporation, and GEA Airexchangers, Inc. In these meetings, proposed program content was discussed and suggestions were received regarding ways that the proposed activities could be of maximum benefit to manufacturers and users of dry cooling systems. These suggestions are included in Section 6 . 


\subsection{Steam Turbine Manufacturers}

In most utility and architect engineer visits, the present unavailability of suitable steam turbines for large dry cooled power installations was mentioned as one of the major obstacles to the rapid adoption of dry cooling. To determine the reasons for the unavailability of suitable turbines, contacts were made with the two largest manufacturers of steam turbines in the United States, General Electric and Westinghouse.

At the present, Westinghouse is not apparently in a position to quote prices and delivery on high back pressure steam turbines (up to $15 \mathrm{in}$. $\mathrm{Hg}$ ) suitable for plants utilizing dry cooling towers. However, they will warrant 1800 rpm nuclear plant-type turbines for a certain number of operating hours at back pressures up to $8 \mathrm{in}$. Hg. This is done to accommodate short time periods of maximum demand on the cooling system, particularly for wet cooling towers. They have no plans to provide this feature on $3600 \mathrm{rpm}$ units as applied to most fossil fueled stations. General Electric has developed the necessary technology to quote prices and delivery for larger steam turbines for fossil fueled plants, and they are supplying the turbine for the 330 MWe Wyodak Plant. They are unable to quote prices and delivery for high back pressure units for nuclear service nor are they certain when they will be able to do so. The technological hurdles associated with the combination of high back pressure and the large steam flow rates inherent to nuclear plants are apparently formidable.

The problems involved in producing a suitable turbine that will accommodate the high back pressures inherent to dry cooled installations are described in detail in Section 5.2. The manufacturers contacted indicated that solutions to most of these problems could be engineered. However, continued development and the investment required for manufacture of such units will be made only if a market develops, and at present, this market seems uncertain.

\subsection{Architect Engineers}

It was understood that many of the architect engineer firms (A\&E's) involved in power plant design and construction have been involved in 
economic and/or design studies of dry cooled installations. In this initial

effort, three major A\&E firms, Bechtel, R. W. Beck and Associates, and Stearns-Roger Corporation, were contacted to obtain specific information, the extent of their envolvement, and any results or input that may be pertinent to the AEC DCT program. 


\subsection{DESCRIPTION OF DRY COOLED INSTALLATIONS OPERATING AND UNDER CONSTRUCTION}

The Black Hills Power and Light Company's Neil Simpson Station was visited to examine the design and operating experience of the Number 5 unit and its air-cooled condenser and to observe the construction site for the 330 MWe Wyodak Plant.

\subsection{Nei1 Simpson Station Unit 5}

The Neil Simpson Station is located 6 miles east of Gilette, Wyoming, and adjacent to one of the world's largest coal seams. The Number 5 unit of this plant, which vas placed into service in 1969, is equipped with an air-cooled condenser. It is the first central station power plant in the Western Hemisphere to use dry cooling.

The Number 5 unit is a coal fired 20 MWe unit which produces $205,000 \mathrm{lb} / \mathrm{hr}$ steam at $850 \mathrm{psi}$ and $900^{\circ} \mathrm{F}$. The exhaust steam from the turbine flows to an air-cooled condenser manufactured by GEA. Six fans, $18 \mathrm{ft}$ in diameter, force anbient air through the fin-tube heat exchangers of the condenser. The ambient air temperatures varies from $-40^{\circ} \mathrm{F}$ to $100^{\circ} \mathrm{F}$ with an average of about $42^{\circ} \mathrm{F}$ dry bulb and $36^{\circ} \mathrm{F}$ wet bulb. The unit was designed for $75^{\circ} \mathrm{F}$ ambient temperature and $4.5 \mathrm{in}$. $\mathrm{Hg}$ condenser pressure. However, when the ambient temperature rises above $75^{\circ} \mathrm{F}$ (near $95^{\circ} \mathrm{F}$ ), the condenser pressure is operated at short periods at pressures up to 7.0 in. $\mathrm{Hg}$. A maximum of $0.8 \mathrm{MW}$ is required to power the fans. In the winter, fan speed is reduced to control back pressure and to prevent freezing.

The condenser heat exchange units are arranged in an "A-frame" configuration with horizontal fans located beneath. Air flow direction is vertical upwards. The construction is modular-type with each fan supplying air to one A-frame heat exchange module. The steam flow is downwards in the primary condenser modules (co-current condensate flow) and upwards in the secondary condenser modules (counter-current condensate flow). Residual air is extracted from the top header to the secondary condenser modules by the plant evacuation system. 
The principal material of construction of the fin tube heat exchangers is steel. After assembly of the stamped sheet steel fins on the tubes, the whole assembly is galvanized to bond the fins to the tube and to limit corrosion.

The whole air-cooled condenser is installed above the turbine building structure and is surrounded on four sides by a vertical windscreen. A horizontal wire net hail screen is provided above the heat exchangers.

From discussions with operating personnel, it was found that dependability of this unit has been excellent. A plant availability of $97.5 \%$ was claimed. Five tubes in the heat exchangers received damage from freezing condensate. The freezing was attributed to both an operator error and a design problem which caused a maldistribution of steam among the vertical heat exchanger tubes in the vicinity of a reducer in the steam supply header. Instrumentation was not installed to detect impending freezing and the incident was not detected until physical damage occurred. These distorted tubes were temporarily repaired and will be replaced during a scheduled outage in the fall of 1975. From visual examinations of the interior of the cooling tower components during shutdown, they were judged to be relatively free of observable corrosion. However, iron oxide is showing up in the boiler at the rate of 20 to $100 \mathrm{lb} /$ year and carrying over to deposit on the turbine blades. These deposits caused shutdown for removal by sandblasting after 2 years operation. The exact source of the iron oxide is not known, but corrosion of the steel heat exchange tubes is one possibility being considered by plant personnel.

Also located at the Neil Simpson Station is a small $3000 \mathrm{~kW}$ unit equipped with an air cooled condenser. The condenser tubes are made of admiralty metal, 1 in. in diameter and $30 \mathrm{ft}$ long. The tubes have $21 / 2 \mathrm{in.}$ diameter aluminum fins. The condenser tubes are mounted horizontally above four $12 \mathrm{ft}$ diameter six-blade fans, two of which are reversible. The fan enclosure is provided with manually operated shutters on the sides. A set of thermostatically controlled shutters are provided above the condenser tubes. Freeze protection is accomplished by setting up recirculating air flows by manipulation of the manual shutters and the reversible fans. 
This $3000 \mathrm{~kW}$ unit was put into operation in 1962 and has been in continuous operation except for scheduled maintenance.

In conclusion, the operation of both units at Neil Simpson appears to be very satisfactory. Although larger dry cooling tower installations may or may not utilize the direct condensing concept, some of the problems encountered in the operation of these installations may be similar to those experienced in the Neil Simpson units. Therefore, it appears advisable to continue surveillance of the Neil Simpson units as a part of the DCT program activities.

\subsection{Wyodak Plant}

The Wyodak Plant is a 330 MWe central power station under construction adjacent to the Neil Simpson Station by Black Hills Power and Light and Pacific Power and Light. The steam conditions will be 1800 psig and $1000^{\circ} \mathrm{F}$ with $1000^{\circ} \mathrm{F}$ reheat. The plant will use a GEA air-cooled condenser similar in configuration to the Neil Simpson Number 5 unit. Initial operation of the plant is scheduled for February 15, 1978, with a commerical operation on May 1, 1978.

Air-cooling was selected for this plant to enable its location at this water-short "mine mouth" location. Such water as is required for plant operation will be obtained by reclaiming waste water discharged by the city of Gilette, Wyoming, sewage treatment plant. Gillette is located 6 miles west of the plant site and the treated sewage will be piped to the plant site where additional treatment will be applied before it is used for plant operation.

When completed, the Wyodak plant will be the world's largest single air-cooled power plant. It will provide the unique opportunity for the study of the performance and reliability of large direct condensing cooling towers and power systems. The results of such a study could provide a valuable basis for the adoption of air-cooling technology by other utilities and the extrapolation of this technology to power systems of larger capacity. 


\subsection{ADVANTAGES OF DRY COOLING}

All utility representatives contacted generally agreed that the most important advantage of the dry cooling of central power stations is the absence of the consumptive use of large quantities of water for heat rejection. The adoption of dry cooling was seen to benefit the individual utilities by allowing them to either

a. Meet projected increases in system demand by plant additions despite forecasted unavailability of water in future years due to either the depletion of existing water supplies or by reason of competition for available water by an expanding population, agriculture and industry;

b. Locate plants at sites of fuel resource availability, load centers or transmission corridors; or

c. Locate plants so as to avoid political and regulation problems.

One utility representative saw dry cooling as being a potentially important method to extend existing supplies of water if retrofit of presently operating plants could be effectively accomplished.

Generally, the lack of a visible plume from a dry cooled installation was not considered as a major benefit by the utilities surveyed. In the regions served by some of these utilities, wet towers do not frequently produce objectionable plumes. Other utilities have experienced little public objection to the visible plumes. Only one utility considered the plume from a wet cooling tower objectionable, and the reason for this was safety oriented, since the potential exists for icing of nearby highways and roads during freezing weather.

General Atomics pointed out that the plume from a large cooling tower may be actually beneficial by cleansing the local atmosphere of pollutants. $^{(1)}$ This plume can entrain large amounts of local polluted air (up to $370 \%$ of the tower air flow) and cause it to rise up to 5000 to $9000 \mathrm{ft}$,

1) Boyack, B. E. and D. W. Kearney, "Plume Behavior and Potentia1 Environmental Effects of Large Dry Cooling Towers," Gulf General Atomic Report GA - A12346, February 1973. 
thereby dispersing the pollution over a larger area. This strongly rising heated plume should also tend to break up low-lying temperature inversions in the vicinity of the cooling tower. 


\subsection{PROBLEM AREAS OF CONCERN TO INDUSTRY}

\subsection{Costs}

In general, all utilities placed the projected high cost of owning and operating dry cooled central power stations as the most important factor currently limiting the application of dry cooling towers. The references listed below ${ }^{(1-5)}$ were mentioned by one or more of the utilities as the source of the evidence upon which this conclusion was based. In these references, somewhat different assumptions were used regarding plant sizes, economic bases, system types and plant locations, so direct comparisons between predicted costs of dry cooling carnot be made. However, from examination of the results of these studies, some idea can be obtained on the approximate economic penalties associated with use of dry cooling over more conventional cooling methods.

In the WEST Associates report prepared by Bechte1, estimates of costs were made of a two-unit coal fired plant located in southcentral Utah at the site of the Kanab coal field. Four types of heat rejection systems were considered: wet cooling towers, a cooling pond, mechanical draft and natural draft dry cooling towers. The results indicated that dry cooling has highest power generation costs, and penalties of 0.9 and $0.91 \mathrm{mi11} / \mathrm{kW}-\mathrm{hr}$ were associated with the mechanical and natural draft towers respectively over wet cooling towers (1971 costs). The corresponding penalty of the cooling pond option was found to be $0.65 \mathrm{mill} / \mathrm{kW}-\mathrm{hr}$. In a similar study for Montana Power Company, Bechtel estimated the penalties associated with the use of dry instead of wet towers for the coal fired, 800 MW Colstrip

1) Olesen, K. A., et al., "Dry Cooling for Large Nuclear Power Plants," Westinghouse Power Generation Systems Report GEN-72-004, February 1972.

2) Rossie, J. D., et al., Cost Comparison of Dry-Type and Conventional Cooling Systems for Representative Nuclear Generating Plants, March 1972.

3) "Comparison of Wet and Dry Cooling Towers for Colstrip Units Nos. 3 and 4," Bechtel Corporation Report prepared for Montana Power Company, May 1974.

4) McFeran, D. E., "Dry Cooling Tower Economic Study," Report to Seattle City Light, Project 72-4, Apri 11973.

5) "Dry Cooling Towers Study," Bechtel Corporation Report prepared for WEST Associates, Apri1 1971. 
Units 3 and 4 which will be constructed in eastern Montana. It was concluded that dry cooling would cost $\$ 8.5$ to $\$ 11.9$ million more per year in operating costs $(1979$ costs). This amounts to a penalty of approximately 0.9 to $1.2 \mathrm{mill} / \mathrm{kW}-\mathrm{hr}$ using the same plant factors as used in the WEST study.

The Westinghouse, Beck and McFeran studies examine the cost penalties of using dry cooling for nuclear power stations. The Westinghouse study examines a 1100 MW nuclear plant in the Philadelphia area which would be built in 1978. It was concluded that the penalty associated with the use of dry cooling over wet cooling towers would be $1.4 \mathrm{mi} 11 / \mathrm{kW}-\mathrm{hr}$ (1978 costs).* In the Beck study, 860-928 MW plants were examined in their different locations, in the northeast, southeast and western United States. In general, it was found that penalty for dry cooling was approximately $0.9 \mathrm{mill} / \mathrm{kW}-\mathrm{hr}$ for all locations. This represents a $12 \%$ increase in energy costs over evaporative cooling. The McFeran study considers a $1200 \mathrm{MW}$ plant in western Washington. The penalty associated with dry cooling was found to be about 0.7 to $0.8 \mathrm{mill} / \mathrm{kW}-\mathrm{hr}$ over wet cooling towers.

The generating costs of a dry cooled plant are higher than a plant with a wet cooling tower system because of several reasons. In the first place, capital costs of the plant are much higher because of the large and costly dry cooling tower and associated systems. For example, in the Bechtel Colstrip study, the additional total capital cost penalty was estimated as $\$ 25,668,000$ and $\$ 24,938,000$ depending on the type of steam turbine employed. Secondly, a dry cooled power station will in most cases be somewhat less efficient than a similar wet cooled plant operating at high dry-bulb temperatures because of the higher heat rejection temperatures. Therefore, fuel costs will also be somewhat higher. At very low dry-bulb temperatures, a dry cooled plant with a turbine designed for high

* Some concern was expressed by several contacts regarding what they consider as "overly-conservative" assumptions used in this study. They feel that the penalties associated with dry cooling as predicted by this study may be somewhat high. 
back pressure may not show an enhanced efficiency because of possible choking in the turbine at very low condenser pressures. Thirdly, a dry cooled power station cannot generally produce full rated output on a high temperature day. This means that the loss of energy produced must be compensated for by the utilization of excess installed capacity in the unit or in the utility system or by purchase or exchange of energy with intertied utilities. The penalty associated with this loss of output can be considerable. For example, considering the Bechtel Colstrip study again, this penalty was between $\$ 5,024,000$ and $\$ 8,222,000$ per year and constitutes from 60 to $70 \%$ of the total penalty associated with dry cooling.

It is generally recognized, however, that the higher inherent costs of dry cooling can be ameliorated if its use can lead to compensating decreases in other cost factors such as fuel transportation costs or water costs. This is apparently the situation which makes the Neil Simpson Station Unit Number 5 very attractive. A study (1) was made of comparative costs of the Number 5 unit which is a dry cooled mine mouth plant located at Wyodak, Wyoming, with the Ben French Unit Number 1 which is a similar wet cooled plant located at Rapid City, South Dakota. Ben French Number 1 uses coal transported from the Wyodak site. This Wyodak site is characterized by its plentiful fuel supplies, but almost total lack of cooling water. It was found that the total energy cost for the Neil Simpson Number 5 unit was $79 \%$ of that of the Ben French Number 1 unit. In this case, the absence of fuel transportation costs more than compensated for the higher costs of the air cooled unit.

All utilities contacted realize that, as water becomes scarce due to competition for existing supplies by an expanding population, agriculture and industry, the cost of water will increase and eventually place wet cooling systems at a disadvantage with respect to dry systems. The time at which this will occur will vary from region to region and could occur in some places as early as 1985 (see Section 2.1).

1) Westre, W. J., "U.S. Experience with Air Cooled Condensers," paper presented to the American Power Conference, Chicago, IL, Apri1 1971. 


\subsection{Turbine Selection}

A second problem of concern with both utilities and A\&E firms contacted was the general unavailability of large turbines suitable for use in dry cooled power stations.

Turbines designed for conventionally cooled plants are designed to operate at back pressures ranging from less than 1.0 to $4.0 \mathrm{in}$. Hg abs with maximum design back pressure of about $5.5 \mathrm{in}$. Hg. Optimization studies have indicated that in a plant with dry cooling towers, maximum back pressures may range to $15 \mathrm{in}$. Hg during hot summer months. In winter, back pressures as low as $1.0 \mathrm{in}$. Hg could be experienced. Large steam turbines of conventional design cannot meet these severe performance requirements. However, systems may be designed to reduce these high back pressures somewhat with the penalty of higher power costs.

General Electric Company has developed sufficienc information to quote prices and delivery* for large steam turbines having ratings up to 650 MWe for operation at exhaust pressures up to $15 \mathrm{in}$. of $\mathrm{Hg}$ in fossil fueled plants, and are supplying the 330 MWe unit for the Wyodak Plant. However, they are unable to quote prices and delivery for high back pressure units for nuclear service nor are they certain when they will be able to do so. Westinghouse apparently is not prepared to quote prices and delivery on high back pressure turbines at this time. Other turbine manufacturers were not contacted during this initial effort.

The problems of designing a turbine for the high back pressures associated with a dry cooled plant include the following:

- The design must accommodate the high differential expansion between the turbine rotor and casing.

- Additional heating of the exhaust hoods and foundation will occur, which must be considered in the design.

- Blade vibration may occur.

* General Electric Company, Marketing Information Letters 922, 946 and 1017. 
- Aerodynamic heating of the turbine blades may occur at off-design conditions.

- High bending stresses will occur on the blades due to high back-end loading.

- Fluttering and buffeting of the blades may occur during certain circumstances.

- There is a greater potential for overspeed during sudden load changes which must be prevented by special controls.

The efficiency of a high back pressure turbine should be nearly as good as low back pressure units. However, a reduction in overall plant efficiency will come as a result of the higher effective heat rejection temperatures-not with any significant increase of the thermodynamic irreversibility of the turbine itself.

It was generally indicated that the problem associated with high back pressure turbines listed above are not insurmountable and can be engineered around. However, this would require a research and development investment which can be justified only if a market for these turbines develops, and at present, the potential size of this market and its rate of development is uncertain.

\subsection{Experience and Reliability}

One of the major concerns of most of the utilities and A\&E firms contacted was the uncertainty over the reliability and lifetime of dry cooling towers and associated equipment. The relatively short operating experience with large dry cooling towers does not provide a solid basis on which to project component lifetime and reliability over the projected 35 to 50 year lifetime of a power generation station.

Although dry cooling towers have been in service in the petrochemical industry for a considerable period of time, these units were not generally designed with long service 1 ife as a primary design criteria and do not provide the experience required to assure the durability of existing designs and materials. 
In the Colstrip study performed by Bechtel, the lifetime was "realistically" estimated as 15 years based on the "opinion of heat exchanger manufacturers." This would mean that the dry cooling tower heat exchangers would have to be changed at least once during the lifetime of the plant. On the other hand, one dry cooling tower vendor claimed that there is no reason to expect that his galvanized steel heat exchangers will not last the full life of the plant based on actual power plant experience. However, with the projected accelerated use of aluminum fin tube designs, lifetime becomes more uncertain especially in areas of atmospheric contamination. Additional lifetime concerns were expressed regarding hybrid cooling tower concepts, and especially those units using treated sewage for makeup. In such units, backsplash or water contaminants recirculated through the atmosphere could have a very deleterious effect on 1 ifetime due to air side corrosion and solids deposition.

About two dozen dry cooled power stations have been built or are under construction in Europe, Africa and Asia. (1) In these locations, electrical utilities do not experience summer peak demands as in the United States. Therefore, the energy and capacity penalties associated with high ambient temperature operation described in Section 5.1 are not as important. The resulting more favorable economics has led to the more widespread use of dry cooling in these locations. The utilities and A\&E firms generally recognize that much valuable operational and reliability information is being obtained in these foreign installations. However, many express the concern that the general small average size of these plants and their relatively recent construction (the oldest plant was started up circa. 1960) does not provide a solid technological bas is to enable design scaleup to 800 to 1200 MWe plants with $35+$ year 1 ifetime.

Most utilities questioned took a very conservative approach to scaleup (extrapolation) of power plant technology. Most stated that they would prefer to observe the operation of a dry cooled plant for a period of time

1) Rossie, J. P. and E. A. Cecil, "Research on Dry-Type Cooling Towers for Thermal-Electric Generation," EPA Report 16130EES11/70, 1970. 
before they would feel comfortable in building a similar plant. The range of allowable plant capacity scaleup factors mentioned by the utilities ranged from 110 to $150 \%$. The construction of the $330 \mathrm{MW}$ Wyodak plant by PP\&L and Black Hills Power and Light from experience gained from the $20 \mathrm{MW}$ Neil Simpson Number 5 unit was considered a very bold extrapolation by other utilities. However, the supplier of the Wyodak air cooled direct condensing system observed that this $330 \mathrm{MW}$ installation is only a $150 \%$ extrapolation over the capacity of the Utrillas Station (Spain) which has been in operation for a number of years. This extrapolation is within the acceptable $110-150 \%$ range suggested by utilities.

\subsection{Operational Problems}

The utilities, A\&E's and vendors express concern over a number of various operation problems associated with dry cooled power plants. The most frequently mentioned included freezeup, water treatment, dependence on weather conditions and potential long term degradation of heat transfer performance.

\subsubsection{Freezeup Problems}

Freezeup of the dry cooling tower heat exchangers during cold weather is a major problem in direct condensing and Heller system (contact condenser) dry cooling towers where no anti-freeze substance may be used. The large exposed heat transfer surfaces are susceptible to rapid cooling during plant load fluctuations and weather changes. If freezing occurs, there is a potential for severe damage to the heat exchangers which may cause extended outages for thawing and repair. An example of such an event was a minor freezeup which occurred in the Neil simpson Number 5 unit. The cause of this event was attributed to a combination of a design fault and an operator error and resulted in the distortion of several finned heat exchanger tubes in a primary condenser section. Repairs to the damaged tubes were effected during operation, and no plant outage resulted from this incident.

Freeze protection can be accomplished by maintaining the proper balance of air and steam/water so that freezing temperatures are not approached anywhere in the dry cooling tower heat exchanger. The reduction of air flow 
through the dry heat exchanger in the winter can be accomplished by either changing fan speed or adjusting a system of louvers. The operation and surveillance of the air flow control system adds a new dimension of complexity to normal plant operations. Furthermore, the dependability of louver operation during driving snow or a freezing rain is questionable.

Another method of preventing freezing in indirect systems is to reduce the heat exchange area by draining heat exchanger systems and removing them from service in extreme cold and low load operation. A planned shutdown or loss of load must be followed immediately by the rapid draining of the entire tower into underground storage tanks. It is not known if such a system would be sufficiently flexible to be used on anything but a base loaded plant.

In indirect systems utilizing surface condensers, freezing may be prevented by the use of a nonfreezing fluid in the condenser-cooling tower recirculating flow system. However, this technique may introduce other design and materials selection problems.

Plant startup in freezing weather is a very exacting process; the procedure must be planned with precision and executed rapidly and precisely. The heat transfer surfaces must be reated sufficiently to raise their temperatures sufficiently to avoid freezing of the inside steam condensate or cooling water. The turbine admission valves and tower draft must be controlled to prevent either excessive exhaust pressure or freezing tower temperatures during startup.

\subsubsection{Water Treatment}

In a direct condensing or Heller system cooling tower, condensate comes in direct contact with the extensive internal surface area of the heat exchanger tubes providing a considerable opportunity for chemical interaction (corrosion) and air intrusion. The chemical treatment of the condensation must balance the requirements for both boiler and heat exchangers if the overall plant 1 ife is to be maximized. Such balance is not easily accomplished. 
In-leakage of air or other noncondensible can occur as a result of damage or defective heat exchanger components and connections or as a consequence of operating conditions such as draining or air introduction to prevent turbine overspeeding following a loss of turbine load. Such air or other noncondensibles must be continuously and effectively removed or else condensation will be adversely affected and/or accelerated corrosion can occur.

Experience at the Neil Simpson Number 5 unit appears to affirm industry concern regarding air and corrosion problems. Iron oxide is showing up in the boiler and carrying over to deposit on the turbine blading. Excursions of iron content of the boiler water from the "normal" $0.1 \mathrm{ppm}$ to $18 \mathrm{ppm}$ have been observed during startup. The iron content, however, rapidly returns to normal after a short period. These turbine deposits required removal by sandblasting after 2 years of operation. One possible source of this oxide is thought to be corrosion of the steel condenser tubes in the dry cooling tower. The exact source of the oxygen and the corrosion site is not known at this time.

\subsubsection{Dependence on Weather Conditions}

The cooling ability of a dry cooling tower depends on the ambient dry-bulb temperature and not the wet-bulb temperature. It is a known phenomena that the dry-bulb temperature fluctuates over a broader range during a typical day than the wet-bulb tamperature. Therefore, the performance of a dry cooling tower will vary over a larger range than wet units. If a peak demand coincides with the highest temperatures, the penalties in heat rate and capacity could be considerable. The strong influence of something as unpredictable as the weather on plant capacity is a disconcerting factor in long range utility planning activities.

\subsubsection{Long Term Degradation of Performance}

The degradation of the heat transfer performance of fintube heat exchangers used in dry cooling tower application can result from several different mechanisms: 
- External corrosion and deposition of atmospheric contamination forming a surface film of high thermal resistance.

- Fouling on the interior tube surface.

- Air flow blockage can occur from the entrapment of lint, seeds and other airborne materials.

- Corrosion attack, thermal cycling and mechanical vibration which can cause deterioration of the thermal contact between the fins and the body of the tube.

The performance and life span of heat exchangers can be improved by occasional washdowns and mechanical cleaning of solids. Also deterioration can be limited by the application of exterior surface coating. At the present time, a number of coatings are being evaluated, but no conclusions have been reached regarding their long term effectiveness.

The degradation of the thermal contact at the fin root is of particular concern because original performance cannot be easily restored. One vendor described laboratory tests where an approximate $20 \%$ reduction in the overal 1 heat transfer coefficient was experienced in identical tests of a test panel performed several months apart. This reduction was attributed to the degradation of the thermal bond between the fin and tube. Although similar events occurring in dry cooling towers have not been documented, the potential for performance degradation certainly exists especially with spirally wrapped and groove tube configurations. 


\subsection{INDUSTRY COMMENTS ON PROGRAM CONTENTS AND SCHEDULES}

This section is concerned with comments and suggestions received from the industry representatives contacted regarding the way in which the Dry Cooling Tower Program could best respond to the needs of the industry.

\subsection{Dry Cooling Practice and Experience}

Most utilities contacted are aware of the expanding use of dry cooing towers for power stations in foreign countries through various journal accounts, publicity, etc. However, few have any detailed knowledge of the design criteria and details and operating experience associated with these power stations. A majority of the utilities feel that objectives of this program could best be served by survey, analysis and dissemination of foreign practice and experience in dry cooling.

Several suggestions were received that any survey of experience should be expanded to include air coolers in the process industry. Air coolers have been used in gas compressor stations, refineries and process plants for several decades. A study of carefully selected installations would provide valuable information of predicting life expectancies of aluminum and steel tubes used in power plant cooling towers. Another application that would provide relevant data is jacket water coolers for pipeline compressor stations. These coolers have about the same fluid temperature and atmospheric conditions (temperature and pollutants) as found near typical power plants. Their size is small in comparison to a power plant, but many have been in operation for several decades at service conditions very nearly the same as those projected for dry cooled power stations. An analys is for the performance of these coolers could produce valuable projections of reliability and lifetime of similar power installations.

\subsection{Costs}

Three areas where it was suggested that the Dry Cooling Tower Program could possibly make a significant contribution are: 1) improved cost definition and 2) reduction of the cost of owning and operating a dry c001ing power station and 3) developing advanced and innovative cooling concepts for discharging heat to the environment. 


\subsubsection{Cost Definition}

In Section 5.1, some of the cost studies of dry cooled, fossil and nuclear power stations were briefly described. These studies resulted in a range of power cost penalties for dry cooling from 0.7 to $1.7 \mathrm{mill} / \mathrm{kW}-\mathrm{hr}$ due to different economic assumptions and construction locations. Many utilities appear uneasy with the range of this data and several suggested that a significant program contribution can be made by: 1) obtaining improved cost data on dry cooling towers, associated auxillary equipment, and turbines, 2) independently assessing the costs of a dry cooled power plant making a special effort to optimize all systems for varying fuel, water and transmission costs, and 3) updating existing studies to quantify the effect of rapidly changing economic parameters such as the value of auxiliary power.

\subsubsection{Cost Reduction}

It was noted in Section 5 that the unfavorable economics was the principle factor preventing the widespread usage of dry cooling for central power stations. One of the important ways that the Dry Cooling Tower Program can make a significant contribution is through performance of research and development to reduce the overall costs of owning and operating a dry cooled plant.

It was suggested that a reduction of these overall costs must be accomplished by concurrent consideration of all of the following factors:

- Heat transfer performance

- Manufacturing costs

- Maintenance costs

- Durability (1ifetime)

- Power cycle arrangements and interactions

The improvement of any one or more of these factors will not necessarily result in the improvement in overall costs if it causes the other factors to be less favorable. In other words, any improvements made in any of the above factors through research and development must be tested by determining their influence on overall costs through the system and plant optimization process. 
Special warnings were received from the dry cooling tower vendors not to expect any breakthroughs on improving heat transfer performance of extended surface heat exchange configurations. This area has already been extensively considered and well documented. However, much of the available data must be organized and reassessed to enable an orderly optimization of overall dry cooling systems.

\subsubsection{Innovative and Advanced Systems}

A number of suggestions were received on advanced or innovative systems which should be examined from the standpoint of reducing costs, improving performance or ameliorate the special problems of dry cooling. These suggestions included the following:

- "Hybrid" wet-dry systems

- Fluidized beds

- Intermediate fluid transferring heat to the dry cooling tower by evaporation and condensation

- Absorption refrigeration systems

- Binary (Bottoming) power cycles

Several of these systems have already received some attention and preliminary study. Furthermore, the "hybrid" system already looks sufficiently attractive to a number of utilities contacted to warrant special attention in the program.

\subsection{Steam Turbines}

The steam turbine manufacturers contacted generally feel that this program could be of benefit to them if the following areas were considered:

- Develop advanced cooling concepts that would reduce turbine back pressure both during base operating conditions and during short time maximum demands.

- Evaluate coupled effects between the turbine and the dry cooling tower during transient conditions.

- Observe and update turbine operation experience of existing installations. 
The need to develop methods to reduce and stabilize turbine back pressure furnished additional incentive to look beyond present dry cooling technology with its inherent dependency of back pressure on the ambient temperatures to the advanced systems mentioned in Section 6.2.3.

\subsection{Demonstration and Qualification Testing}

One topic which received considerable discussion during these visits was the potential usefulness of demonstration and qualification testing of "off-the-shelf" dry cooling tower modules offered by the various vendors. The suggestion was received prior to the start of the program planning activities that such testing could possibly provide the necessary data and operational information to enable utilities and their A\&E's to more confidently specify existing technology equipment and extrapolate the demonstrated technology to larger central power stations. The possible benefits of such demonstration and qualification testing were reviewed with the industry representatives contacted, and views were solicited on its potential usefulness and validity.

The responses received from the firms contacted were varied. The majority of utilities generally commented that "any information that could be gained may be useful" and that qualification testing done on a modular basis would probably be valid and useful when conditions were such that they must consider dry cooling. On the other hand, two of the dry cooling tower system vendors provided detailed arguments that there is nothing to be gained from qualification and demonstration testing, and one of these pointed out that testing performed on a modular basis would not necessarily be extrapolatable to systems consisting of assemblies of modules. The third vendor observed that demonstration and qualification testing may provide the operating experience for indirect systems under adverse weather conditions that might serve to qualify these systems for immediate use in this country. Al1 vendors agreed that technology is proceeding at such a pace that any module tested would probably be obsolete before the end of the testing program.

The responses from the A\&E firms were also varied. The personnel of one A\&E firm were sharply divided over the issue of the usefulness of 
qualification and demonstration of existing products. The second A\&E firm declined to comment on the validity of such testing.

The suggestion was received from several firms that the goal of enhancing utilities confidence in existing technology could be better attained through study, analysis and reporting of experience with existing power installations including both foreign plants, the Neil Simpson Number 5 Unit, and the Wyodak plant. This was discussed in Section 6.1.

In summary, it is apparent that the agruments against the validity of demonstration and qualification testing are substantial and the strong support of such activity will not be forthcoming from the industry.

\subsection{Miscellaneous Problems of Dry Cooling}

A number of miscellaneous concerns about various aspects of dry cooling were observed to exist, especially amoung the utilities contacted. Although some cannot be considered of pivotal importance, they still constitute unknowns which must be addressed at some point in the program. Several of these concerns are as follows:

- Affect of dry cooled installations on the environment

- Fan noise

- Vibration of large dry cooling towers

- Seismic and tornado resistance

- Corrosion, especially in salt atmospheres 


\subsection{SUMMARY AND CONCLUSIONS}

The following is an itemized surmary of pertinent information gathered during the initial phase of the industrial visitation subtask of the Dry Cooling Tower Program. It is planned that this information will be used in program planning and scheduling to insure that the program's results are timely and relevant to general industry needs. The detailed program plan will be described in a document scheduied for transmittal for comment to interested utilities, vendors and A\&E's in January 1975.

1. Power stations with dry cooling towers are generally more expensive to own and operate than plants with evaporative towers. This added expense is a result of a) higher capital costs and b) energy and capacity penalties associated with degraded performance during high ambient temperatures.

2. In future years, water will become scarce in some regions of the U.S. because: a) ground water is being depleted and b) the competition for existing supplies from a growing population, agriculture and industry is rapidly increasing. This scarcity will cause the price of water to rise.

3. When water prices become sufficiently high, dry cooling towers for central power stations will become economically attractive. In at least one location in the U.S. this is already true (Wyodak, Wyoming); other utilities predict rising water costs will cause them to turn to dry cooling in the 1980's and beyond.

4. It is important to start now to develop R\&D information on which to base the design of dry cooled plants that will be built in the mid 1980 's.

5. To fulfill the program objective to encourage the early adoption of dry cooling by utilities, the most important activity is to decrease overall costs of owning and operating such a plant. With decreased costs, dry cooling will become economically competitive earlier. 
6. Costs can be decreased by improving and optimizing present designs and by developing advanced systems. Advanced systems which decrease energy and capacity penalties could be particularly significant to high summer peak utilities. This program should contain R\&D activities aimed at both cost reduction methods, but should emphasize the latter because of possible enhanced returns.

7. Utilities generally feel uneasy about the prospect of designing and operating large dry cooled plants, because no such plants have been built and there is no experience available in their operation.

8. Dry cooling towers have been used in the process industry for decades. However, the design criteria for these will differ from a power station cooling tower and will not provide the experience base required by the utilities. Nevertheless, the process industry could be a valuable source of scientific data to enable projections of corrosion behavior and lifetimes.

9. Demonstration and qualification testing of existing technology modules of various vendors may furnish some useful information on the performance of these products. However, the value of this information may be limited because of the following reasons:

- There is a reasonable question regarding the extrapolatability of information obtained on one module to a power plant cooling tower consisting of large assemblies of modules.

- The modules tested would possibly be obsolete before the end of testing because of the rapid rate of advancement of technology.

Since the testing of existing products will not result in any significant reduction of the cost of dry cooling, it will not solve the principal problem of dry cooling, i.e., high cost, and will not significantly advance the date at which dry cooling will become a viable alternative for utilities. 
10. Although utilities are generally aware of the extensive use of dry cooling for power plants in foreign countries, few have access to the detailed designs and operating experience associated with these plants. Information of this type could provide the confidence in dry cooling which could ease its adoption by the utility industry. Therefore, high priority should be given in the Dry cooling Tower program to survey, collect, analyze and report this foreign experience.

11. Large steam turbines designed for dry cooled power plants are not presently available. The unavailability is not due to insurmountable technical difficulties, but because the market is not large enough to justify research and development expenditures.

12. The study and development of advanced systems which lower and stabilize turbine back pressure should be given high priority, since it may not only help reduce energy and capacity penalties, but may also permit the use of current technology turbines.

13. Studies of corrosion and lifetime should be given high priority because these are two of the greatest and costliest unknowns at present.

14. Operational unknowns defined in Section 6.3 should be considered, but at some lower priority than improved and advanced systems development. 


\section{APPENDIX I}

\section{LISTING OF INDUSTRIAL CONTACTS THROUGH AUGUST 1974}

\section{UTILITIES}

American Electric Power

H. J. Jazon

Arizona Public Service Company

Tom Woods

Lyman Munth

Dr. Ray Carey

Dale Thornberg

Kent Stern

Black Hills Power and Light Company

W. J. Westre

Ray Van Horn

Consolidated Edison Company of New York, Inc.

Carl L. Newman

Los Angeles Department of Water and Power
J. L. Mulloy
K. 0. Cartwright
H. R. King
Sam Sugine

Montana Power Co.

Roger Hofacher

Bob Labbie

R. N. Sykes
Presentation to Montana Department of Natural Resources (Project member in attendance)

Northeast Utilities

Robert H. Meyer

Gerald L. Holm

Pacific Gas and Electric

F. F. Mautz

E. E. Hall

D. V. Kelly

Paul Levin

J. F. McKenzie

E. D. Myers

J. E. Schumann

J. 0. Schuyler

Norm Ziomek 
UTILITIES (contd)

Public Service of Colorado

R. F. Walker

F. W. Eastom

Larry Burt

W. E. Wos tenberg

J. A. Nelson

G. W. Liljenberg

San Diego Gas and Electric

Robert G. Lacy

Seattle City Light
R. L. Skone
J. W. LaFond
T. H. Reid

Southern California Edison

J. Lynn Rasband

Robert S. Grove

J. W. C. Racine

Utah Power and Light

F. N. Davis

STEAM TURBINE MANUFACTURERS

General Electric Co., Large Steam Turbine Division

E. H. Miller

D. Scoffield

W. Steffennagen

Westinghouse Electric Corp., Steam Turbines Division

R. 0. Brown

Joseph Davids

B. Stimpson

ARCHITECT ENGINEERS AND CONSULTANTS

Bechtel Corporation

Paul Leung

G. R. Retti

Stearns-Roger Corporation

H. J. Bell

J. Y. Parce

R. W. Beck and Associates

John P. Rosisie 
DRY COOLING TOWER VENDORS

GEA Airexchangers, Inc.

Bill Davis

Hudson Products

E. C. Smith

M. W. Larinoff

Marley Company

$$
\begin{aligned}
& \text { Jim Kadel } \\
& \text { Joe Ben Dickey } \\
& \text { Bob Cates } \\
& \text { Dick Landon } \\
& \text { John Nelson } \\
& \text { John McArtor }
\end{aligned}
$$

OTHERS

Power Generation Cooling Systems

A. C. Smith

EPRI (Electric Power Research Institute)

R. W. Zeren

G. J. Silvestri, Jr.

HTRI (Heat Transfer Research Institute Inc.)

J. E. Taborek

J. W. Clegg

Jim Chenoweth

PFR Engineering Systems
J. M. Pundyk
M. L. Baltay
D. T. Kuo

General Atomic Company
T. W. Schoene
D. J. Kowal
D. Nelson
E. 0 . Winkler
A. H. Gibeling
H. P. Fay
Bob Potthoff

Westinghouse Electric Corp., Power Cooling Systems Department

K. A. Oleson 
BNWL -1878

UC-38, Special

Distribution

DISTR IBUTION

No. of

Copies

OFFSITE

1 AEC Chicago Patent Group

U.S. Atomic Energy Commission 9800 South Cass Avenue Argonne, IL 60439

A. A. Churm

1 AEC Office of Assistant General Counsel for Patents U.S. Atomic Energy Commission Washington, DC 20545

8 AEC Division of Reactor Research \& Development U.S. Atomic Energy Commission Washington, DC 20545

Assistant Director, Engineering \& Technology

G. W. Cunningham

Deputy Assistant Director, Engineering \& Technology
A. J. Pressesky

Chief, Engineering \&

Components Development Branch

D. H. Groel sema

J. D. Nulton (4)

Chief, Advanced Concepts

Evaluation Branch

T. Beresovski

27 AEC Technical Information Center

$1 \quad$ Allied Chemical Company 550 2nd Street Idaho Falls, ID 83401

B. R. Dickey
No. of

Copies

1 Aluminum Company of America

Alcoa Technical Center

Alcoa Center, OH 15069

R. 011 ie

1 American Electric Power 2 Broadway New York, NY 10004

H. J. Janon

1 Arizona Publ ic Service Company

2121 West Cheryl Drive

Phoenix, AZ 85021

T. Woods

1 Carolina Power \& Light

Company

356 Fayettesville Street

Raleigh, NC 27602

J. Sel1

1 Commonwea 1th Edison

One First Plaza

P. 0. Box 767

Chicago, IL 60690

Robert H. Holyoak

1 Consolidated Edison

Company of New York, Inc.

4 Irving Place

New York, NY 10003

Cart L. Newman

1 Curtiss Wright Corporation

One Passaic Street Wood Ridge, NJ 07075

R. C. Haberski 
No. of

Copies

1 Electric Power Research

Institute

3412 Hil1view Avenue

P. 0. Box 10412

Palo Alto, CA 94304

R. W. Zeren

1 GEA Airexchangers, Inc. 46 Worthington Drive Maryland Heights, MD 63043

B. Davis

1 General Atomic Company

P. 0. Box 81608

San Diego, CA 92138

T. W. Schoene

1 General Electric Company

Large Steam Turbine Division 300 Nott Street

Schenectady, NY 12301

E. H. Miller

1 Heat Transfer Research Inc. 1000 S. Fremont Avenue Alhambra, CA 91802

J. E. Toborek

2 Hudson Products 6855 Horwin Drive Houston, TX 77036

E. C. Smith

M. W. Larinoff

$1 \quad$ Marley Company

5800 Fox Ridge Drive

Mission, KS 66202

R. Landon

1 Massachusetts Institute of

Technology

77 Massachusetts Avenue

Cambridge, MA 02139

L. R. G1 icksman
No. of

Copies

$1 \quad$ Northeast Utilities

P. 0. Box 270

Hartford, CT 06101

Robert H. Meyer

$1 \quad$ Pacific Gas and Electric

77 Beale Street

San Francisco, CA 94106

F. F. Mautz

$1 \quad$ PFR Engineering Systems

1417 South Georgia Street

Los Angeles, CA 90015

J. M. Pundyk

1 Power Generation Cooling

Systemis

$4714-52$ nd St. South

Seattle, WA 98118

A. C. Smith

1 Public Service of Colorado 5900 East 39th Avenue

Denver, CO 80207

R. F. Walker

1 Public Service of New

Mexico

Corporate Planning

Department

A1buquerque, NM 87103

Roger Jones

1 San Diego Gas and Electric

101 Ash Street

San Diego, CA 92107

Robert G. Lacy

1 Seattle City Light

1015 Third Avenue

Seattle, WA 98104

R. L. Skone 
No. of

Copies

1 Southern California Edison 2244 Walnut Grove Avenue Rosemead, CA 91770

J. Rasband

1 Stone and Webster Engineering Corporation P. 0. Box 2325 Boston, MA 02107

D. H. Guild

1 Union Carbide Corporation ORGDP - K-25 P. 0. Box D

Oak Ridge, TN 37803

George J. Kidd

1 United Engineers \&

Constructors

1401 Arch Street

Philadelphia, PA 19105

G. A. Engelson

1 University of Iowa

Hydraulic Research Institute Iowa City, IA 52240

J. F. Kennedy

$1 \quad$ Utah Power and Light 1407 West North Temple

Salt Lake City, UT 84103

F. N. Davis

1 West Associates

Sierra Pacific Power Co.

100 E. Moana Lane

Reno, NV 89510

G. H. Soule
No. of

Copies

2 Westinghouse Electric

Corporation

Steam Turbines Division

Lester Branch

Box 9175

Philadelphia, PA 19113

R. 0. Brown

K. A. Oleson

ONSITE

1 Westinghouse Hanford

Company

Hanford Engineering

Development Laboratory

J. Fletcher

42 Battel le

D. E. Deonigi/J. W. Currie

J. G. DeSteese

D. W. Faletti

J. W. Finnigan

B. C. Fryer

J. J. Fuquay

C. H. Henager

A. B. Johnson/G. E. Zima

W. S. Kelly

R. S. Kemper/P. A. Ard

C. J. Knoll

R. P. Marsha 11/R. L. Dillon

L. T. Pedersen

H. C. Riches/J. B. Schuette

A. M. Sutey

D. S. Trent/Y. Onishi

R. D. Widrig

R. K. Woodruff

F. R. Zaloudek (20)

Technical Information Library (3)

Technical Publications 